\title{
Experimental enhancement of neurphysiological function
}

\author{
Diana Deca ${ }^{1 *}$ and Randal A. Koene ${ }^{2}$ \\ ${ }^{1}$ Center for Integrated Protein Science and SyNergy Cluster, Institute of Neuroscience, Technical University Munich, Munich, Germany \\ ${ }^{2}$ Carboncopies.org Foundation, San Francisco, CA, USA \\ *Correspondence: diana.deca@/rz.tum.de \\ Edited by: \\ Mikhail Lebedev, Duke University, USA \\ Reviewed by: \\ Mikhail Lebedev, Duke University, USA \\ Ioan Opris, Wake Forest University, USA
}

Keywords: experimental enhancement, optogenetics, single cell electrical stimulation, whole brain emulation, artificial general intelligence

Enhancing brain function entails controlling neuronal function. There are several methods available for this which led to some relevant experimental data. Deca (2011) Since methods for connectome (Briggman et al., 2011; Prevedel et al., 2014) and circuit functional analysis (Marblestone et al., 2013) are advancing rapidly (Deca, 2012), it makes sense to consider only the most convincing neurophysiological data in the context of enhancement and their future development.

\section{STIMULATION METHODS: ELECTRICAL AND OPTICAL}

The Brecht lab (Houweling and Brecht, 2008) has achieved training of a biological neural network in the living animal through a single neuron leading to enhanced learning speed. Microstimulation of the monkey frontal eye fields (FEF) (Goldberg et al., 1986) and training (Ferrera and Lisberger, 1995) can induce eye fixation and use neuronal activity as a predictor for saccadic eye movements (Shadlen and Newsome, 2001). Schiller and Tehovnik mapped the neurophysiological basis of saccadic eye movements (Tehovnik and Lee, 1993) as a basis for a visual prosthetic (Schiller and Tehovnik, 2008).

Optogenetics is by now a stock neuromodulation technique. The Deisseroth lab used it to enhance neuronal direction selectivity through optical stimulation of interneurons (Lee et al., 2012). Increasing inhibition can promote learning. It was also used to modulate the astroglial activation (Perea et al., 2014) for enhancing both excitatory and inhibitory neurotransmission. Neuronal activity can also be inhibited optogenetically (Zhang et al., 2007) using halorhodopsin.

\section{NEUROFEEDBACK}

Romo et al. (2000) used microstimulation as a substitute for sensory stimulation and obtained the same results, showing that sensory input can be replaced in a network by its corresponding electrical input. Furthermore, it was shown that rhesus monkeys can control the activity of their own FEF neurons, when experimenters reinforce visual attention (neurofeedback training Schafer and Moore, 2011).

The finding that rats can press a lever in order to get drugs that interfere with their own dopaminergic system (Yokel and Wise, 1976; Wise et al., 1990) also inspired the invention of an electrode for chronic brain self-stimulation.

\section{NEURAL PROSTHETICS}

The discovery of neural population coding of directional motor control signals (Georgopoulos et al., 1982, 1986), plus the discovery of stable cortical maps for motor control (Ganguly and Carmena, 2009), have enabled control of prosthetic limbs through chronic multi-site neural interfaces in non-human primates (Nicolelis, 2001; Graziano et al., 2002; Nicolelis et al., 2003; Gilja et al., 2012) and human experiments with implantable devices that enable control of a cursor, a wheel chair, a TV remote control, and a prosthetic hand by a single neuron or by an ensemble of neurons (Kennedy and Bakay, 1998; Hochberg et al., 2006; Truccolo et al., 2008; Simeral et al., 2011). There are also efforts to use signals from higher-level cognitive processing to instruct devices (Andersen et al., 2004). The FDA has approved clinical trials for cortical motor control of prosthetic arms using Utah arrays (Maynard et al., 1997).

Work from the Schreiner lab (Atencio et al., 2014) shows that an auditory implant in the thalamus can give better results than cochlear implants.

Also, a short-term memory neuroprosthetic in the rodent hippocampus enhanced performance (Berger et al., 2011). It performed real-time diagnosis and stimulation and enhanced cognitive, mnemonic processes. Furthermore, one can transfer performance-related spiking activity from one donor brain and use this pattern to stimulate another and generate the same behavior through BMBI. Deadwyler et al. (2013), Opris et al. (2001, 2013), Opris and Casanova (2014), Berger and Deadwyler made a neuroprosthetic multi-input multi-output (MIMO) model replicating CA3-to-CA3 coding functions which successfully enhanced monkeys' performance on a decision making task (Dibazar et al., 2013; Hampson et al., 2013) and recovered it under pharmacological disruption (Hampson et al., 2012). They are currently starting trials in volunteer human patients. Guggenmos et al. (2013) invented a prosthetic for restoring motor function. Circuit function was also emulated in the cerebellum (Herreros et al., 2014). Using the neuroprosthetic system, a rat underwent acquisition, retention and extinction of the eye-blink reflex even under anesthesia. 
Table 1 | Summary of successful neurophysiological enhancements.

\begin{tabular}{|c|c|c|c|}
\hline Enhanced function & Method & What is modulated & Possible developments \\
\hline $\begin{array}{l}\text { Learning/Decision } \\
\text { making }\end{array}$ & $\begin{array}{l}\text { Single neuron electrical } \\
\text { stimulation }\end{array}$ & Neuronal firing/Behavior & $\begin{array}{l}\text { Enhancing a desired behavioral response through } \\
\text { electrical stimulation }\end{array}$ \\
\hline Oculomotor control & Neurofeedback training & $\begin{array}{l}\text { Neuronal firing in the } \\
\text { FAF/thalamic }\end{array}$ & $\begin{array}{l}\text { Inducing long-term plasticity and learning through } \\
\text { repetitive neurofeedback training }\end{array}$ \\
\hline Hearing & Auditory thalamic implant & Thalamic input & $\begin{array}{l}\text { Activated auditory cortex at low electrical current } \\
\text { levels }\end{array}$ \\
\hline Vision/Fixation & Electrical stimulation & Frontal eye fields & Electrically evoked saccadic eye movements \\
\hline Memory & Neuroprosthetic & Neuronal firing/behavior & $\begin{array}{l}\text { Enhanced mnemonic processes through electrical } \\
\text { stimulation }\end{array}$ \\
\hline Motor skills & $\begin{array}{l}\text { Brain-machine-brain interface } \\
\text { (BMBI) }\end{array}$ & $\begin{array}{l}\text { Bridged damaged neural } \\
\text { pathways }\end{array}$ & $\begin{array}{l}\text { Promoted LTP, } \\
\text { Restored motor function }\end{array}$ \\
\hline Learning & Neuroprosthetic & $\begin{array}{l}\text { Restored the eye-blink reflex } \\
\text { under anesthesia with BMBI }\end{array}$ & $\begin{array}{l}\text { Induced learning in the cerebellum with } \\
\text { neuroprosthetic conditioning }\end{array}$ \\
\hline
\end{tabular}

\section{TOWARD THE CONNECTOME}

The goal of this paper was to present the clearest experimental evidence of neurophysiological enhancement to date, while employing a very conservative definition of enhancement.

The neural mechanisms for the enhancement effects of drugs, deep brain stimulation or transcranial current stimulation are largely unknown. Microstimulation and optogenetics provide means to control specific system components and study their contribution to a particular brain function. Neuroprosthetics, brain implants, MIMO, BMBI, and neurofeedback training do electrophysiological data acquisition, interpretation and reimplementation which, if successful, show a clear direction of causality of the neurophysiological substrate of sensing, learning, memory and decision making. These approaches provide mechanistic explanations together with clear enhancement of brain functions.

In the near future, more mechanistic/causal electrophysiological data showing enhancement in lower animals will enable further exploration of these mechanisms in primate non-human and human subjects. A significant challenge for non-invasive experimental enhancement is getting around the isolating effects of the skull. Lebedev (2014) if this cannot be achieved, then very small invasive implants (Seo et al., 2013) may be an alternative solution.

\section{ACKNOWLEDGMENTS}

We would like to thank Anders Sandberg (Oxford University), Leslie Seymour (PersInVitro) and Antje Birkner (Technical University Munich) for their inspiring comments and suggestions.

\section{REFERENCES}

Andersen, R. A., Burdick, J. W., Musallam, S., Pesaran, B., and Cham, J. G. (2004). Cognitive neural prosthetics. Trends Cognit. Sci. 8, 486-493. doi: 10.1016/j.tics.2004.09.009

Atencio, C. A., Shih, J. Y., Schreiner, C. E., and Cheung, S. W. (2014). Primary auditory cortical responses to electrical stimulation of the thalamus. J. Neurophysiol. 111, 1077-1087. doi: 10.1152/jn.00749.2012

Berger, T. W., Hampson, R. E., Song, D. Goonawardena, A., Marmarelis, V. Z., and Deadwyler, S. A. (2011). A cortical neural prosthesis for restoring and enhancing memory. J. Neural Eng. 8:046017. doi: 10.1088/1741-2560/8/4/046017

Briggman, K. L., Helmstaedter, M., and Denk, W. (2011). Wiring Specificity in the DirectionSelectivity circuit of the retina. Nature 471, 183-188. doi: 10.1038/nature09818

Deadwyler, S. A., Berger, T. W., Sweatt, A. J., Song, D., Chan, R. H. M., Opris, I., et al. (2013). Donor/recipient enhancement of memory in rat hippocampus. Front. Syst. Neurosci. 7:120. doi 10.3389/fnsys. 2013.00120

Deca, D. (2011). Available tools for whole brain emulation. Int. J. Mach. Conscious 04, 67. doi: 10.1142/S1793843012400045

Deca, D. (2012). The Connectome, WBE and AGI. Artif. Gen. Intell. Lect. Notes Comp. Sci. 7716, 41-49. doi: 10.1007/978-3-642-35506-6_5

Dibazar, A. A., Yousefi, A., and Berger, T. W. (2013). "Multi-layer spike-in spike-out representation of Hippocampus circuitry," in Proceedings of the 6th International IEEE/EMBS Conference on Neural Engineering (NER) (San Diego, CA), 613-616.

Ferrera, V. P., and Lisberger, S. G. (1995). Attention and target selection for smooth pursuit eye movements. J. Neurosci. 15, 7472-7484.

Ganguly, K., and Carmena, J. M. (2009). Emergence of a stable cortical map for neuroprosthetics. PLoS Biol. 7, 1-13. doi: 10.1371/journal.pbio. 1000153

Georgopoulos, A. P., Kalaska, J. F., Caminiti, R., and Massey, J. T. (1982). On the Relations Between the direction of two-dimensional arm movements and cell discharge in primate motor cortex. J. Neurosci. 2, 1527-1537.

Georgopoulos, A. P., Schwartz, A., and Kettner, R. E. (1986). Neuronal population coding of movement direction. Science 233, 1416-1419.

Gilja, V., Nuyujukian, P., Chestek, C. A., Cunningham, J. P., Yu, B. M., Fan, J. M., et al. (2012). A highperformance neural prosthesis enabled by control algorithm design. Nat. Neurosci. 15, 1752-1757. doi: $10.1038 / \mathrm{nn} .3265$

Herreros, I., Giovannucci, A., Taub, A. H., Hogri, R., Magal, A., Bamford, S. A., et al. (2014). A cerebellar neuroprosthetic system: computational architecture and in vivo experiments. Front. Bioeng. Biotechnol. 2:14, doi: 10.3389/fbioe.2014.00014 
Goldberg, M. E., Bushnell, M. C., and Bruce, C. J. (1986). The effect of attentive fixation on eye movements evoked by electrical stimulation of the frontal eye fields. Exp. Brain Res. 61, 579-584.

Graziano, M. S. A., Taylor, C. S. R., and Moore, T. (2002). Complex movements evoked by microstimulation of precentral cortex. Neuron 34, 841-851. doi: 10.1016/S0896-6273(02)00698-0

Guggenmos, D. J., Azinc, M., Barbaya, S., Mahnkend, J. D., Dunhama, C., Mohsenic, P., et al. (2013). Restoration of function after brain damage using a neural prosthesis. Proc. Natl. Acad. Sci. U.S.A. 110, 21177-21182. doi: 10.1073/pnas.1316885110

Hampson, R. E., Gerhardt, G. A., Marmarelis, V., Song, D., Opris, I., Santos, L., et al. (2012). Facilitation and restoration of cognitive function in primate prefrontal cortex by a neuroprosthesis that utilizes minicolumn-specific neural firing. J. Neural Eng. 9:056012. doi: 10.1088/17412560/9/5/056012

Hampson, R. E., Song, D., Opris, I., Santos, L. M., Shin, D. C., Gerhardt, G. A., et al. (2013). Facilitation of memory encoding in primate hippocampus by a neuroprosthesis that promotes task-specific neural firing. J. Neural Eng. 10:066013. doi: 10.1088/1741-2560/10/6/ 066013

Hochberg, L. R., Serruya, M. D., Friehs, G. M., Mukand, J. A., Saleh, M., Caplan, A. H., et al. (2006). Neuronal ensemble control of prosthetic devices by a human with tetraplegia. Nature 442, 164-171. doi: 10.1038/nature04970

Houweling, A. R., and Brecht, M. (2008). Behavioural report of single neuron stimulation in somatosensory cortex. Nature 451, 65-68. doi: $10.1038 /$ nature 06447

Kennedy, P. R., and Bakay, R. A. (1998). Restoration of neural output from a paralyzed patient by a direct brain connection. Neuro Rep. 9, 1707-1711.

Lebedev, M. (2014). Brain-machine interfaces: an overview. Transl. Neurosci. 5, 99-110. doi: 10.2478/s13380-014-0212-z

Lee, S. H., Kwan, A. C., Zhang, S. Phoumthipphavong, V., Flannery, J. G., Masmanidis, S. C., et al. (2012). Activation of specific interneurons improves V1 feature selectivity and visual perception. Nature 488, 379-383. doi: 10.1038/nature11312

Marblestone, A. H., Zamft, B. M., Maguire, Y. G., Shapiro, M. G., Cybulski, T. R., Glaser, J. I., et al. (2013). Physical principles for scalable neural recording. Front. Comput. Neurosci. 7:137. doi: $10.3389 /$ fncom. 2013.00137
Maynard, E. M., Nordhausen, C. T., and Normann, R. A. (1997). The utah intracortical electrode array: a recording structure for potential brain-computer interfaces, electroencephalography and Clinical. Neurophysiology 102, 228-239.

Nicolelis, M. A. L. (2001). Actions from Thoughts. Nature 409, 403-407. doi: 10.1038/35053191

Nicolelis, M. A. L., Dimitrov, D., Carmena, J. M., Crist, R., Lehew, G., Kralik, J. D., et al. (2003). Chronic, multisite, multielectrode recordings in macaque monkeys. Proc. Natl. Acad. Sci. U.S.A. 100, 11041-11046. doi: 10.1073/pnas. 1934665100

Opris, I., Barborica, A., and Ferrera, V. P. (2001). A gap effect during microstimulation in the prefrontal cortex of monkey. Exp. Brain Res. 138, 1-7. doi: $10.1007 /$ s002210100686

Opris, I., and Casanova, M. F. (2014). Prefrontal cortical minicolumn: from executive control to disrupted cognitive processing. Brain 137(Pt 7), 1863-1875. doi: 10.1093/brain/awt359

Opris, I., Santos, L. M., Song, D., Gerhardt, G. A., Berger, T. W., Hampson, R. E., et al. (2013). Prefrontal cortical microcircuits bind perception to executive control. Sci. Rep. 3:2285. doi: 10.1038/srep02285

Perea, G., Yang, A., Boyden, E. S., and Sur, M. (2014). Optogenetic astrocyte activation modulates response selectivity of visual cortex neurons in vivo. Nat. Commun. 5, 3262. doi: 10.1038/ncomms4262

Prevedel, R., Yoon, Y.-G., Hoffmann, M., Pak, N., Wetzstein, G., Kato, S., et al. (2014). Simultaneous whole-animal 3D imaging of neuronal activity using light-field microscopy. Nat. Methods 11, 727-730. doi: 10.1038/nmeth.2964

Romo, R., Hernandez, A., Zainos, A., Brody, C. D., and Lemus, L. (2000). Sensing without touching: psychophysical performance based on cortical microstimulation. Neuron 26, 273-278. doi: 10.1016/S0896-6273(00)81156-3

Schafer, R. J., and Moore, T. (2011). Selective attention from voluntary control of neurons in prefrontal cortex. Science 332, 1568-1571. doi: 10.1126/science. 1199892

Schiller, P. H., and Tehovnik, E. J. (2008). Visual prosthesis. Perception 37, 1529-1559. doi: 10.1068/p6100

Seo, D., Carmena, J. M., Rabaey, J. M., Alon, E., and Maharbiz, M. M. (2013). Neural Dust: An Ultrasonic, Low Power Solution for Chronic BrainMachine Interfaces, arXiv:1307.2196 [q-bio.NC].

Shadlen, M. N., and Newsome, W. T. (2001). Neural basis of a perceptual decision in the parietal cortex (area LIP) of the rhesus monkey. J. Neurophysiol. 86, 1916-1936.

Simeral, J. D., Kim, S. P., Black, M. J., Donoghue, J. P., and Hochberg, L. R. (2011). Neural control of cursor trajectory and click by a human with tetraplegia 1000 days after implant of an intracortical microelectrode array. J. Neural Eng. 8, 1-24. doi: 10.1088/1741-2560/8/2/025027

Tehovnik, E. J., and Lee, K. (1993). The dorsomedial frontal cortex of the rhesus monkey: topographic representation of saccades evoked by electrical stimulation. Exp. Brain Res. 96, 430-442. doi: 10.1007/BF00234111

Truccolo, W., Friehs, G. M., Donoghue, J. P., and Hochberg, L. R. (2008). Primary motor cortex tuning to intended movement kinematics in humans with tetraplegia. J. Neurosci. 28, 1163-1178. doi: 10.1523/JNEUROSCI.4415-07.2008

Wise, R. A., Murray, A., and Bozarth, M. A. (1990). Bromocriptine self-administration and bromocriptine-reinstatement of cocainetrained and heroin-trained lever pressing in rats. Psychopharmacol 100, 355-360.

Yokel, R. A., and Wise, R. A. (1976). Attenuation of intravenous amphetamine reinforcement by central dopamine blockade in rats. Psychopharmacology 48, 311-318.

Zhang, F., Wang, L. P., Brauner, M., Liewald, J. F., Kay, K., Watzke, N., et al. (2007). Multimodal fast optical interrogation of neural circuitry. Nature 446, 633-639. doi: 10.1038/nature05744

Conflict of Interest Statement: The authors declare that the research was conducted in the absence of any commercial or financial relationships that could be construed as a potential conflict of interest.

Received: 31 May 2014; accepted: 17 September 2014; published online: 08 October 2014.

Citation: Deca D and Koene RA (2014) Experimental enhancement of neurphysiological function. Front. Syst. Neurosci. 8:189. doi: 10.3389/fnsys.2014.00189

This article was submitted to the journal Frontiers in Systems Neuroscience.

Copyright (C) 2014 Deca and Koene. This is an openaccess article distributed under the terms of the Creative Commons Attribution License (CC BY). The use, distribution or reproduction in other forums is permitted, provided the original author(s) or licensor are credited and that the original publication in this journal is cited, in accordance with accepted academic practice. No use, distribution or reproduction is permitted which does not comply with these terms. 